HStud 22 (2008) 1-2, 157-167

DOI: 10.15566/HStud.22.2008.1-2.11

\title{
DRAWING INSTRUCTION AND THE CULTIVATION OF TASTE: HUGÓ SZEGEDY-MASZÁK'S VIEWS ON DRAWING INSTRUCTION IN PRIMARY SCHOOLS
}

\author{
ZSUZSANNA SZEGEDY-MASZÁK \\ Eötvös Loránd University, Budapest \\ Hungary
}

\begin{abstract}
This article situates the ideas on drawing instruction of Hugó Szegedy-Maszák within the larger context of shifting trends in conceptions of art and art education. It considers the pedagogy outlined in his 1871 handbook on drawing instruction and the ideas expressed in two later essays of a more theoretical nature, which were written in part under the influence of his exposure to the ideas of American, German, and English art pedagogues at the Paris World Congress of 1900. Essentially, Hugó Szegedy-Maszák viewed art instruction not merely as an occasion to develop drawing as a practical skill, but as an opportunity to cultivate and refine taste.
\end{abstract}

Keywords: art education, pedagogy, drawing instruction, taste, aesthetics, Paris World Fair, Paris World Congress, Hugó Szegedy-Maszák, Kálmán Györgyi

\footnotetext{
"It is among the foremost of pressing duties, in my opinion, to cultivate the taste of the people (...) For this reason the ministry will recognize the necessity of making sweeping reforms concerning our entire approach to the instruction of drawing, in part by making drawing instruction an obligatory subject in every educational institution and also by establishing national public drawing schools at the expense of the state."
}

Hugó Szegedy-Maszák published three longer writings on drawing instruction in primary schools. The first of these, a practical handbook entitled Utmutató az elemi rajztanitásban (Guide to Elementary Drawing Instruction), was written for teachers in the late 1860s. Decades later he approached the subject matter from a more theoretical and methodological point of view, the fruit of which, an essay entitled $A$ rajztanitás a párisi kiállitáson és teendöink (Drawing instruction at the Paris World Fair and the tasks that await us), was submitted to the Ministry of Education and published in the art journal Mücsarnok (Kunsthalle). ${ }^{2}$ The third and last of Szegedy-Maszák's texts, similar in approach and subject matter but larger in scale, appeared in 1906 in the journal Budapesti Szemle (Budapest Review). 
Hugó Szegedy-Maszák was born in 1831 in the town of Aiud (Nagyenyed), Romania and received most of his schooling there at the reformed Bethlen College. In 1848 he fought in the revolutionary army, but following the devastation caused by the uprising led by Romanian popes Axente Sever and Prodan Simion he fled the city, only to return to the college in 1851 as instructor of drawing and calligraphy. Six years later he moved permanently to Pest, as did many of the intellectuals of the city. In Aiud he had become acquainted through his friend Nicholas Zeyk with so-called Talbot photography. In Pest he began taking drawing and painting lessons from renowned painter Miklós Barabás and acquired knowledge of how to make lithographs. At this time he frequently drew and wrote for contemporary Hungarian journals, among them Vasárnapi Újság (Sunday Paper) and Pesti Napló (Pest Journal). In addition, his essays and critiques on exhibitions, art, linguistics, and education appeared in numerous literary and political periodicals, such as Magyarország (Hungary) and Ország (Nation). In the summer of 1863 he traveled with Zsigmond Kemény to see art collections in Germany. Of this trip he writes in his diary, "I began to see." In 1866 he married Ilona Barabás, one of Miklós Barabás' daughters, with whom he had ten children. As his own private endeavor in 1864 he began the short-lived art periodical Magyar Képzömüvész (Hungarian Artist) $^{3}$ and from 1868 to 1869 he edited Kunsthalle, the journal of the Association of Fine Arts. ${ }^{4}$ In 1871 Minister of Religion and Education Tivadar Pauler appointed him as the secretary of the newly formed Council of Fine Arts, a position he held for 18 years. At the request of József Eötvös, minister of education and religious affairs at the time, he participated on the national board on school textbooks. In addition to evaluating works submitted for competitions by elementary students, together with his fellow board members (the school inspectors József Menyei and László Nagy) he collaborated in designing illustrations to be used in schools the majority of which were based on works by Hungarian masters. ${ }^{5}$ During this time he wrote his instructor's handbook entitled Guide to Elementary Drawing Instruction, a publication that was soon translated into German for use by the Budapest Israelite Teacher's College (an English translation was also commissioned by the Ministry) and was used in Hungarian state primary schools for decades. ${ }^{6}$ In 1882, in the interests of freeing the Hungarian press from the pressures of the Viennese news agency, he established the Hungarian News Agency, which he headed for 16 years. In 1887 he was granted nobility. The letter concerning this states,

in recognition of your achievements in the areas of public education and the fine arts you are most graciously granted Hungarian nobility and the use, exempt from any fees, of the "Pesti-Szegedy" title of nobility. $^{7}$

He died in 1916. 


\section{The Historical Antecedents of Drawing Instruction in Primary Schools in Hungary}

In 1777, in accordance with the Ratio Educationis, Maria Theresa made the establishment of drawing schools (schola graphidis) mandatory in royal free boroughs and school districts annexed to the so-called standard schools (schools consisting of four grades), while in municipal schools in which there were at least three teachers and which were able to employ a drawing instructor drawing was made a facultative subject. ${ }^{8}$ The establishment of national drawing schools and the introduction of drawing education, which corresponded for the most part to applied geometry and industrial drawing, was a matter of economic state interest. In these schools most of the drawing instructors were engineers, priests or painters of minor talent, ${ }^{9}$ and the method of instruction and curriculum was set by a 1783 German-language handbook the Hungarian title of which was A cs. kir. államokban létezö normáliskolai rajzosztályok szervezete, rendtartás és a tanitás módszeres utasitásai (The structure, regulations and methodical instruction of drawing classes in standard schools existing within the imperial royal states). This first curriculum of drawing instruction in Hungary prescribed that, "in primary schools drawing should be taught with rulers and compasses as well as free-hand." It was in the spirit of this directive that instruction in national drawing schools and the Sunday drawing schools associated with them was practiced until the public education act of 1868 countermanded drawing schools. ${ }^{10}$ The first Hungarian-language drawing handbook was written in 1804 by Pál Sárvári (17651846), instructor of the reformed boarding-school in Debrecen. ${ }^{11}$ In this he discusses, in addition to the methodology of drawing education, the "taste for beauty." In other words, aesthetic education was a subject of interest as early as the first Hungarian drawing textbook. However, this was written and used only by the students of the boarding-school in Debrecen. ${ }^{12}$

The XXXVIII. statute introduced by József Eötvös in 1868 pronounced that every community in which at least thirty children between the ages of six and twelve live but in which there were no denominational schools would be compelled to establish an elementary school. The elementary school curriculum issued in accordance with this statute in Buda on September $15^{\text {th }}, 1868$ determined that although drawing is not designated as an obligatory subject,

as it is almost the only formative tool for improving visual and manual deftness, which serves the improvement of taste and therefore the improvement of the nation, it is most desirable that where possible this subject should be made part of the curriculum of primary schools. ${ }^{13}$ 
The subsequent curriculum is from 1877. Although it changed little with regards to the material taught, it nevertheless made the instruction of drawing compulsory from the third grade. The most dramatic change was brought about by the Curriculum and Instruction of 1905, which was implemented in the following academic year in all state and municipal primary schools (it did not affect denominational schools). ${ }^{14}$ This established the goal of drawing education as the "development and instruction of the aptitude for observation and illustration in close unity" and placed drawing through observation at the core of instruction: "it leads the child to develop awareness of perception, sharp judgment, and finally the recognition and appreciation of nature and human industry." It was at this point that drawing became an artistic subject in schools. It was also the first time that the importance of viewing works of art was formulated in the official curriculum. Development of an aptitude for observation and depiction, as well as aesthetic and artistic training, were key notions in the curriculum. It repealed the use of pre-dotted pattern sheets and notebooks with net-like dotted lines. However, in practice the curriculum remained impossible to realize. The capital reduced the curriculum and the requirements and in 1913 published a revised version.

In the beginning of June 1905, the Association of Hungarian Drawing Instructors held a three day long general assembly in the Library of the Royal Drawing School. Bertalan Székely and Lajos Rauscher were the presiding chairs. For the most part the assembly discussed drawing in secondary schools, but there was also a debate concerning drawing instruction in primary schools. This revolved around the question of whether drawing should be an independent subject taught in schools or merely a series of exercises designed to improve manual dexterity. According to the minutes of the meeting a wide range of opinions were voiced. József Simkó proposed that the curriculum of head school-inspector Kálmán Györgyi be disregarded. Ultimately the panel decided it was not the opportune moment to take a stand on a single method of teaching. ${ }^{15}$

\section{Guide for Drawing Instruction in Primary Schools}

Hugó Szegedy-Maszák finished his first outline of the Guide for Drawing Instruction in Primary Schools in October of $1868 .{ }^{16}$ He recalls this occasion in his diary in the following manner:

I have been invited to the Ministry of Culture on Sunday to a meeting of drawing instructors with regards to primary school textbooks, of which I have been asked to write the one on drawing method. I have completed the first outline of my proposal (October 22, 1868). ${ }^{17}$ 
The handbook was reviewed and accepted on July $23^{\text {rd }}, 1870$ in a meeting presided over by Lőrinc Imre and Sándor Péterfy and including such members as Antal Ligeti and Gusztáv Kelety, director of the Hungarian Royal Drawing School. It was first published in 1871 in 1,000 copies, followed by another 2,000 copies two years later and subsequent printings in 1879, 1885 and 1899.

The Guide stresses that the instructor should not deviate from the given order, as "just as in the field of sciences, there should be no leaps in the acquisition of art." " The author emphasizes the importance of the knowledge of drawing at the beginning, but one can already discern in his argument the pretension of nurturing good taste. Szegedy-Maszák claims that knowledge of art is necessary in all fields, therefore all children, both boys and girls, should be taught to love drawing. ${ }^{19}$ In an article he wrote decades later he expressed a similar view:

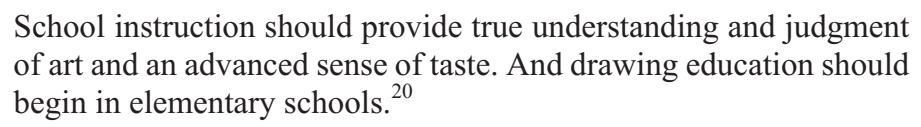

Szegedy-Maszák's teacher's handbook therefore corresponded to the objections of contemporary cultural and educational policy, which was responsible among other initiatives for the foundation of the Hungarian Royal Drawing School (later to become the Academy of Fine Arts). This is no surprise. Given that the book was commissioned by the Ministry of Education, the publication rights belonged to the state and it was in use for decades in state schools.

In his Guide Szegedy-Maszák deviates from the Prussian-type, so called stygmographic method (the essence of which was to copy individual points onto the paper and later connect them with lines). This technique hampers the development of the ability to estimate with the eye. Nevertheless the use of such pre-dotted pattern sheets was common until the publication of the 1905 Official Curriculum. ${ }^{21}$ Instead, Szegedy-Maszák recommends the so-called "drawing-calligraphy" method, i.e., the use of demonstrative images or drawings made on the board by the teacher in front of the children. This approach, which establishes as its goal the correct drawing of various lines, was in use well into the $1930 \mathrm{~s}^{22}$

Szegedy-Maszák considered himself a follower of Rousseau and regarded it as important not to rush children's development. Instead he believed that the goal of drawing instruction should be to aid the free advancement of a child's own abilities. His critiques make plain that his approach to art and his understanding of the importance of drawing are inseparable. As in the assessments of his father-in-law Miklós Barabás, his objections are frequently limited to technical considerations. In other words, it wasn't just the acquisition of artistic tricks of the trade (as it were) that he considered important, but also their maintenance. He claimed that drawing should not be understood strictly as a skill, 


\begin{abstract}
because the mechanical activity of the fingers and the progression of manual skill should advance together with judgment, otherwise where judgment overtakes the hand an artist whose skillfulness is deficient will be the result, one who draws and paints in a faulty manner. $^{23}$
\end{abstract}

\title{
Drawing Instruction at the Paris World Fair and the Tasks that Await Us
}

The content of the article printed in the third issue of Mücsarnok entitled Drawing Instruction at the Paris World Fair and the Tasks that Await Us corresponded for the most part to the report the author handed in to Minister Gyula Wlassics. Its second half, entitled "The tasks that await us," contains his suggestions with regards to reforming drawing instruction in Hungarian schools. According to this:

- Drawing should be a compulsory subject (a view that was accepted by the 1900 Paris Congress) and should begin as early as preschool or the first grade of primary school;

- Imaginative drawing and drawing from memory should be practiced;

- Instruction should focus on drawing scenes from nature;

- The teacher should use a collection of hand-drawings;

- Summer courses should be organized for drawing instructors;

- A superintendent of drawing instruction should be appointed.

\section{Turning Point in the Area of Drawing Instruction}

In 1906 Szegedy-Maszák's essay Fordulat a rajzoktatás terén (Turning point in the field of drawing instruction) was published as an offprint of the journal Budapesti Szemle (Budapest Review). Among other things, it discussed conclusions drawn from lectures given at the 1900 International Drawing Instruction Congress in Paris. Along with another 150 congresses of scientific, industrial, and social interest, this congress complemented the Paris World Fair, which for the most part formulated the theoretical bases of achievements in the arts and sciences on view at the exposition. There were three different groups of delegates at the congresses: those who officially represented the Government, representatives of local and national organizations, and those who attended out of personal interest. Those belonging to the two latter groups paid a membership fee to attend. In 1900 all congresses were organized under the auspices of the Exposition, many of them meeting within the Exposition grounds in the Palais des Congres erected especially for this purpose. The Congress concerned with the teaching of drawing was 
held between August $29^{\text {th }}$ and September $1^{\text {st }} \cdot{ }^{24}$ In all probability Szegedy-Maszák attended the Paris Congress as an official delegate, as in a copy of a letter addressed to Gyula Wlassics (November 15, 1900) he expresses his gratitude for the financial support that he received (600 crowns) and provides the minister with a report several pages in length on the lectures given at the congress. ${ }^{25}$

In addition to the congress an exhibition of school drawings was organized within the confines of the World Fair. Institutions from the United States, Europe and Japan submitted the notebooks of their pupils, from preschool all the way to secondary school. In the course of surveying this Szegedy-Maszák concluded that, "in the infancy of art the adult depicted things as the child does now." It must be noted that behind the reformed pedagogy lies an increase in interest in children's art elicited by Corrado Ricci's 1887 book entitled L'arte dei bambini (The art of children). ${ }^{26}$ Ricci wrote his book on the basis of research he pursued in Bologna. His main thesis was that exaggerations and omissions in children's drawings should not be corrected, but rather appreciated. ${ }^{27}$ The essence of the reformed pedagogy that took form as a result of his book is that the child should be regarded as an autonomous being and the method of instruction should be adjusted to the natural strengths of each individual age group.

Szegedy-Maszák begins his essay with the following statement: "A propitious reform has taken place in recent years concerning drawing instruction methodology in the states of the old and the new worlds." He quotes Rousseau's Emil: "So I shall take good care not to provide him with a drawing master, who would only set him to copy copies and draw from drawings. Nature should be his only teacher, and things his only models. ${ }^{, 2}$ Hereupon he discusses the curriculum provisions of the French public educational ministry (from which the city of Paris deviated) at length. Namely, that although this curriculum divides drawing instruction into free-hand drawing and geometrical parts, even in the free-hand curriculum the use of a ruler and a compass is prescribed, as drawing on the whole was fundamentally centered around the depiction of architectural ornaments. Szegedy-Maszák then turns to a discussion of the lectures and debates that took place during the congress. One such debate, or more precisely a resolution, concerned the future exclusion from schools of the so-called Viennese Hillard-type sketchbooks or any kinds of notebooks in which the pages were divided into grids. He mournfully remarks that in the end the congress decided in favor of upholding the geometrical method. Szegedy-Maszák dwells on three lectures, two given by Englishman Ethal Speeler and German Susanne von Nathusius and one given by the American Mary Colman Wheelert, (principal of a secondary school in Providence, member of the directorate of Brown University's school for girls, and a well-known personality in the literature on drawing education whose name still graces schools in the United States). ${ }^{29}$ 
At the beginning of the last third of the essay, entitled "Turning point at home," Szegedy-Maszák joyfully asserts that, "we have stepped out of the cold, soporific haze of architectural ornaments." He is referring to the fact that István Bárczy, then the director of education in the capital (later mayor, then head mayor), had asked Kálmán Györgyi to lay out a new system and method of drawing instruction. Incidentally it was under Bárczy's three-year plan that 36 new school buildings were built in Budapest. ${ }^{30}$ Györgyi was the school-inspector of lower elementary schools from 1903 and of higher elementary schools from 1917. As such he began the sweeping reforms concerning artistic education in elementary schools. His program was accepted and subsequently he organized courses in which 40 drawing instructors of the capital were trained, then with their help another 250 teachers were introduced to the new method.

He presented the fruits of his endeavors with great success at the International Drawing Education Congresses of 1908 (London) and 1912 (Dresden). ${ }^{31}$ However, prior to these events, Szegedy-Maszák mentions the 1905 drawing exhibition as proof of the efficacy of the new method, of which he says that on the whole, "the capital Budapest has anticipated the policies of the country's government."

The drawing exhibition mentioned in Szegedy-Maszák's last essay is also referred to in the minutes of the meeting of the 1905 general assembly of Hungarian Drawing Instructors. According to this at the end of the first day the participants in the assembly visited the exhibition organized by Kálmán Györgyi, which featured the drawings of elementary school students from the capital. However, Györgyi cancelled the lecture he was to deliver the following day. In the list of more than 200 participants of the assembly the name Hugó Szegedy-Maszák is missing. ${ }^{32}$ Nevertheless, he saw the exhibition and he identifies Györgyi as the person behind the turning point discernible in Hungarian primary school drawing education.

Izsó Szüts wrote his booklet entitled Az elemi rajzoktatás reformja (The Reform of Elementary Drawing Instruction) following the 1900 Paris World Fair. ${ }^{33}$ In this Szüts gives account of lessons that emerged in the course of the Paris exposition, giving special attention to the educational policies of the United States. Of the American drawing exhibition he claims that this was the most frequented educational show: "a swarm of instructors and teachers examined this room, making drawings and taking notes on what they saw." ${ }^{34}$ He then makes proposals for the reformation of drawing instruction in Hungarian elementary schools, the goal of which would be to awaken the students' aptitude for observation, to animate their imaginations, to teach them to draw from memory, and to arouse the desire to work. ${ }^{35}$ The fundamental difference between the booklets of Szüts and SzegedyMaszák is that while the former writes exclusively on the observations made during the exposition, Szegedy-Maszák also emphasizes the conclusions issued at the 
congress, presumably thanks in part to his command of numerous foreign languages.

The introduction and postscript of Szüts's essay was written by Márton Mártonfy, who himself visited the Paris World Fair on assignment from the Ministry and also handed in an official report. ${ }^{36}$ The following quote is from his postscript:

The Paris World Fair marks a new era, a turning point in the field of drawing instruction, as methods have been initiated to cultivate the students' independence, their ability to observe and judge, and their aesthetic sense.

Among Hugó Szegedy-Maszák’s manifold interests, drawing instruction, which in his view was the basis for cultivating artistic taste, occupied a prominent place. In his youth during the fifties in Aiud he applied his views in practice. Fifteen years later he wrote the first state-commissioned Hungarian-language drawing handbook for elementary schools, while his essays published around the turn of the century address the methodology that he deemed correct from a theoretical point of view. The subject and method (the teacher drawing on the board as a guide and the order of teaching first straight and then curved lines) of the Guide written in 1868 and published in 1871 for the most part harmonizes with the contents of the official 1869 elementary school curriculum. Where there are deviations they incline towards the more progressive, for example his conviction that drawing instruction should begin in the first grade (even the official curriculum eight years later only prescribed compulsory drawing classes from the third grade on). His handbook corresponded to the cultural and educational policies represented by ministers József Eötvös and Tivadar Pauler and eloquently articulated by Gusztáv Keleti in his thoughts concerning the cultivation of the nation's taste. In 1900 Szegedy-Maszák again received an official state assignment when minister Gyula Wlassics financed his trip to Paris. In the lectures given at the congress he recognized his own old teaching methodology, which in his view Kálmán Györgyi later realized in Budapest schools from 1905 onwards. The basis of this methodology is the cultivation of perception through the exercise of measure taken by the eye and, in the interests of developing the intellect and judgment, the independent, unmediated observation of nature.

Notes

1 Gusztáv Keleti “Teendőink a képzőművészet ügyében” (Our tasks concerning the fine arts). In Budapesti Szemle (Budapest Review) (1869): 108-134.

2 Mücsarnok (Kunsthalle), 30 (December 9 1900).

3 A journal devoted to the fine arts, archeology and literature, it appeared twice a month between April 1864 and June 1864. Magyar Hirlap-irodalom statisztikája 1780-1880-ig (Statistics of 
Hungarian journals between 1780-1880). Assembled by Antal Szalády, introduction by József Ferenczy (Budapest, 1889), 140.

4 Appeared twice a month between March $3^{\text {rd }}$ and January $16^{\text {th }}, 1869$. Ibid. 160.

5 "His drawings also had a pedagogical aim. He drew demonstrative wall-drawings for schools, together with Thán, Székely, Telepy, Újházi, Orlai Soma and Jakobey Károly (1873).” Károly Lyka: "Szemlér Mihály", Müvészet (Art), 1904: 112-116 (http://www.mke.hu/lyka/ 03/3-2-7-szemler.htm) (Date accessed: November 26, 2007.) The names of the above mentioned painters are from the manuscript letter from ministerial advisor Pál Gönczy (January $23^{\text {rd }}, 1880$ ) (in possession of the author).

6 "I send a manuscript version of the German translation of your work Utmutatás az elemi rajztanitásban by Ábrahám Lederer, principal of the Israelite Teachers' College of Budapest, so that you can examine it and, should any changes be made, bring them to our attention as soon as possible." Budapest, February 18, 1876. Manuscript letter from the ministerial advisor, Pál Gönczy. In connection with the English language version: Manuscript letter from Under-secretary Gedeon Tanárky (in possession of the author).

$7 \quad$ Manuscript letter from Under-secretary Albert Berzeviczy, Budapest, July $12^{\text {th }}, 1887$. (1624) (in possession of the author).

8 Csőregh, Éva. Rajzoktatásunk története (The history of our drawing education), Eidos füzetek (Budapest, 1991), 13.

9 Csőregh, 13.

10 Csőregh, 14.

11 A rajzolás mesterségének kezdete (The beginnings of the craft of draughtsmanship).

12 Csőregh, 16.

13 Csőregh, 47.

14 Csőregh, 48-49.

15 "A magyar rajztanárok orsz. nagygyülésének jegyzőkönyve" (Minutes of meeting of the national assembly of Hungarian drawing instructors) in Magyar Rajztanárok Országos Egyesülete, 8(3) (1905): 143-157.

16 Manuscript entry of Hugó Szegedy-Maszák.

17 Manuscript of Hugó Szegedy-Maszák’s diary, October $22^{\text {nd }}, 1868.103-104$.

18 Utmutató az elemi rajztanításban (hereafter Guide), 7.

19 Guide, 9.

20 "Wlassics rendelete és a múvészi nevelés" (The statute of Wlassics and artistic education). Egyetértés (Accordance) (November 20, 1898): 9.

21 Csőregh, 20.

22 This method used no patterns, the teacher drew on the board and instructed the students with key-words to draw with him/her. Csőregh, 21.

23 Guide, 7.

24 "The Congresses of the Paris Exposition", Science. New Series, 11(283) (June, 1900): 872-874.

25 Letter from Hugó Maszák to Minister Gyula Wlassics (in possession of the author).

26 In Hungarian literature Magyar László Nagy wrote numerous essays and books on the subject, including Fejezetek a gyermekrajzok lélektanából (Chapters on the psychology of children's drawings) (Budapest: Singer és Wolfner, 1905).

27 Ourania Kouvou: "About child art: an examination of the historical identity of an influential art educational practice." Paper presented at the European Conference on Educational Research, University College Dublin, 7-10 September 2005. http://www.leeds.ac.uk/educol/ documents/143833.htm (Date accessed: November 25, 2007). 
English translation by Barbara Foxley. http://www.gutenberg.org/dirs/etext04/emile10.txt (Date accessed: May 26, 2007)

29 "Miss Wheeler was born in Concorde, MA, and studied in Berlin and Paris after having taught in the Concord schools for two years. She established Miss Wheeler's School in 1880. She was a delegate from this country to the Congress of Secondary Schools in Paris in 1900 and to the Congress of Teachers in Berne in 1904." The New York Times (March 11, 1920): 11. http://www.wheelerschool.org.

http://images.google.com/imgres?imgurl=http://www.btm.hu/ihm_anyagok/Ujkor/erdei/img /kepek/02_farbaky_01.jpg\&imgrefurl=http://www.btm.hu/ihm_anyagok/Ujkor/erdei/esszek/ 02_01_epiteszet.html\&h=167\&w=200\&sz $=20 \& \mathrm{hl}=$ en\&start=19\&sig2=eDZvxBfZi55mwX $4 \mathrm{yBNcQoA \& um}=1 \&$ tbnid=3QvkIc-9SCi_vM:\&tbnh=87\&tbnw=104\&ei=SuZJR42MKoeO wAGBsajuCg\&prev=/images $\% 3 \mathrm{Fq} \% 3 \mathrm{D} \% 2522 \mathrm{~B} \% 25 \mathrm{C} 3 \% 25 \mathrm{~A} 1 \mathrm{rczy} \% 2 \mathrm{BIstv} \% 25 \mathrm{C} 3 \% 25 \mathrm{~A} 1$ n\%2522\%26start\%3D18\%26ndsp\%3D18\%26svnum\%3D10\%26um\%3D1\%26hl\%3Den\%2 6rls\%3DRNWE,RNWE:2006-17,RNWE:en\%26sa\%3DN (Date accessed: November 25, 2007)

31 http://www.giergl.hu/index.php?eid=033cb0ba733d95ff\# (Date accessed: November 25, 2007)

32 Although it cannot be completely ruled out that he was present as the list contains only the names of those who registered until May $15^{\text {th }}$. Magyar Rajztanárok Országos Egyesülete, 8(1) (1905): 1-15.

33 Izsó Szüts: Az elemi rajzokatás reformja (A müizlés nevelése) (The reform of drawing instruction in elementary schools. The nurturing of the taste for art) (Budapest, 1901). Reviewed by Károly Holló: "Szüts Izsó Az elemi rajzoktatás reformja" (Izsó Szüts' The reform of drawing instruction in elementary schools). A Magyar Rajztanárok Országos Egyesületének Értesitője, 3(1900): 318-319.

34 Szüts, 15.

35 Szüts, 32.

36 Szüts, 50. 